\title{
smat
}

http://journal.binadarma.ac.id/index.php/olympia

\section{Hubungan Daya Ledak Otot Lengan Dan Koordinasi Mata Tangan Dengan Hasil Chest Pass Siswa Ekstrakurikuler Bola Basket}

Ari Agus Saputra ${ }^{1}$, Agung Mahendra ${ }^{2}$

Universitas PGRI Palembang, Indonesia ${ }^{1}$

Info Artikel

Sejarah Artikel:

Diterima: Januari 2019

Disetujui: Februari 2019

Dipublikasikan: Maret

2019

Keywords: Arm Muscle

Explosion, Hand Eye

Coordination, Chest

Pass

\section{Abstrak}

Penelitian ini bertujuan untuk mengetahui apakah ada hubungan antara Daya Ledak Otot Lengan dan Koordinasi Mata Tangan dengan hasil Chest Pass pada siswa Ekstrakurikuler Bola Basket di SMP Negeri 1 Tanjung Raja. Metode yang digunakan dalam penelitian ini adalah metode korelasi.Teknik pengumpulan data menggunakan teknik tes Two-Hand Medicine Ball Put untuk pengukuran Daya Ledak Otot Lengan dan instrument tes Koordinasi Mata Tangan dengan menggunakan teknik tes lempar tangkap bola tenis dari variabel bebas (x), dan hasil tes melempar menangkap bola sebagai instrument tes Chest Pass dari variabel terikat (y). Populasi pada penelitian ini berjumlah 20 siswa, sampel pada pada penelitian ini berjumlah 20 siswa, teknik pengambilan sampel menggunakan sampling jenuh, berdasarkan hasil pengumpulan data perhitungan daya ledak otot lengan diperoleh niai 0,641 , hasil yang diperoleh dari pemumpulan data koordinasi mata tangan di peroleh nilai 0,977, Hasil yang diperoleh dari perhitungan korelasi ganda diperoleh nilai 0,969, hasil yang diperoleh pada perhitungan chest pass diperoleh nilai nilai F-hitung 13,02 > F-tabel 2,12 maka ho ditolak dan ha diterima artinya terdapat hubungan antara daya ledak otot lengan (X1) dan koordinasi mata tangan (X2) dengan hasil chest pass (Y) pada ekstrakurikuler bola basket di SMP Negeri 1 Tanjung Raja.

\begin{abstract}
This study aims to determine whether there is a relationship between Arm Muscle Explosion Power and Hand Eye Coordination with the results of the Chest Pass on Basketball Extracurricular students at Tanjung Raja 1 Public Middle School. The method used in this study is the correlation method. Data collection techniques used the TwoHand Medicine Ball Put test technique for measurement of Arm Muscle Explosion and the Hand Eye Coordination test instrument using a tennis ball throwing test technique from free variable $(x)$, and the results of the throw test catch the ball as a Chest Pass test instrument of the dependent variable (y). The population in this study
\end{abstract}


amounted to 20 students, the sample in this study amounted to 20 students, the sampling technique using saturated sampling, based on the results of data collection calculation of arm muscle explosive power obtained by 0.641 , the results obtained from hand eye coordination data collection scored 0.977 The results obtained from multiple correlation calculations obtained a value of 0.969, the results obtained in the chest pass calculation obtained a calculated F-value of $13.02>$ F-table 2.12 then ho is rejected and ha is accepted, meaning there is a relationship between the arm's explosive power (X1) and hand eye coordination (X2) with chest pass (Y) results at basketball extracurricular activities at Tanjung Raja 1 Junior High School.

\footnotetext{
Alamat korespondensi: Jl. Jend Ahmad Yani, Lr. Gotong Royong, 9/10 Ulu, Seberang Ulu I, Kota Palembang, Sumatera Selatan 30116

E-mail: agungmahendra@univpgri-palembang.ac.id
}

\section{PENDAHULUAN}

Pendidikan jasmani merupakan salah satu pendidikan yang menggunakan aktivitas fisik. pendidikan jasmani merupakan bagian yang integral dari seluruh proses pendidikan, yang mempunyai tujuan pengembangan warga secara fisik (jasmania), mental, emosional. (Wildan, 2013;694). Olahraga adalah kegiatan fisik yang berbentuk permainan, dilakukan dalam bentuk pertandingan atau perlombaan melawan orang lain, unsur-unsur alam, maupun diri sendiri. Sehubungan dengan hal ini olahraga memiliki beberapa ciri antara lain : adanya aktivitas fisik, adanya kegiatan yang berbentuk permainan, kegiatan di lakukan dalam bentuk pertandingan atau perlombaan, sasaran di arahkan untuk mencapai prestasi setinggi-tingginya (Alnedral, 2015;7).

Olahraga Bola Basket merupakan cabang olahraga yang dimainkan oleh dua regu termasuk dalam permainan bola besar, baik putra maupun putri. Masing-masing regu terdiri dari lima orang pemain dalam setiap pertandingan yang berusaha memasukan bola kekeranjang lawan untuk mendapatkan point. Basket dianggap sebagai olahraga unik karena diciptakan secara tidak sengaja oleh seorang guru olahraga. Pada tahun 1891, Dr. James Naismith, seorang guru olahraga asal Kanada yang mengajar di sebuah perguruan tinggi untuk siswa profesional di YMCA (sebuah wadah pemuda umat kristen) di Springfield, Massachusetts, harus membuat suatu permainan di ruang tertutup untuk mengisi waktu para siswa pada masa musim dingin di New England.

Olahraga basket merupakan olahraga yang menggunakan bola dan di mainkan secara beregu. Tiap regunya di mainkan oleh 5 orang pemain. Olahraga ini pada umumnya di mainkan dalam ruangan tertutup atau indoor. Berbeda dengan yang terjadi di sekolah, dimana olahraga basket lebih banyak di 
mainkan di ruangan terbuka atau outdoor (Mikanda Rahmani, 2014:50).

Pada umumnya di Indonesia Bola Basket sudah tidak asing lagi di kalangan masyarakat di kota-kota besar hingga pedesaan. Khususnya di daerah Ogan Ilir (OI) sekolah-sekolah setiap tahunnya selalu mengadakan perlombaan antar pelajar baik itu tingkat SMP dan SMA. Dalam permainan Bola Basket dikenal berbagai macam teknik dasar dan untuk bisa memainkan olahraga ini harus menguasai teknik-teknik dasar permainan Bola Basket. Ada banyak macammacam teknik dasar dalam permainan ini yaitu : passing (melempar/menangkap), teknik ini adalah yang paling dasar yang terdiri dari mengoper bola dari atas kepala (overhead pass), mengoper dari pantulan (bounce pass), dan mengoper dari depan dada (chest pass) kemudian menangkap (catching), menggiring (dribbling) dan menembak (shooting).

Passing adalah sebuah gerakan dimana seorang pemain mengoper bola yang di bawanya kepada teman satu timnya dengan cara di lempar. Tujuan dari teknik passing ini ialah mencegah tim lawan merebut bola. Mengoper atau melempar bola terdiri dari tiga cara yaitu : melempar bola dari atas kepala (over head pass), melempar bola dari depan dada (chest pass) yang dilakukan dari dada ke dada dengan cepat dalam permainan, serta melempar bola memantul ke tanah atau lantai (bounce pass) (Teguh Susanto, 2016:50).

Adapun teknik gerakan melakukan passing dada (chest Pass) adalah Teknik gerakan melakukan passing dada (chest pass) adalah, Bola di pegang setinggi dada dan nyaris menyentuh tubuh bagian depan. Jari tangan di buka ketika membawa bola, dan menekuk siku. Ketika kita berniat ingin melemparkan bola maka posisi tangan harus ke depan dengan arah telapak tangan menghadap keluar (Nidhom Khoeron, 2017:45).

Dalam peningkatan teknik permainan bola basket dibutuhkan kondisi fisik seperti daya tahan, yaitu selama dalam permainan siswa dituntut untuk tetap dalam kondisi stabil hingga akhir permainan. Kondisi lainya yaitu konsentrasi, dalam permainan baik latihan maupun saat pertandingan di butuhkan konsentrasi sehingga siswa tetap fokus dalam bermain. Kecepatan reaksi dan koordinasi juga dibutuhkan dalam bermaian.

$$
\text { Dalam upaya meningkatkan }
$$

keterampilan olahraga di cabang bola basket perlu usaha yang maksimal dan kerja keras dalam proses latihan serta mempertimbangkan semua faktor yang mendukung. Faktor tersebut antara lain kondisi fisik, metode latihan, koordinasi gerak dan sebagainya. Untuk mendapatkan hasil yang optimal tidak hanya dilihat dari pembinaan dan latihan saja tetapi juga perlu di perhatikan dari dalam siswa (internal).

Adapun beberapa faktor yang mempengaruhi hasil chest pass dalam permainan bola baket, yaitu dibutuhkannya kondisi fisik yang baik. Menurut Syafrudin, (2011: 65), kondisi fisik itu dibedakan atas 
pengertian sempit dan luas. Dalam arti sempit kondisi fisik merupakan keadaan yang meliputi kekuatan (strength), kecepatan (speed), dan daya tahan (endurance). Namun dalam arti luas meliputi ketiga unsur tersebut dan ditambah dengan unsur kelentukan (flekxibility) dan koordinasi (coordination) ( Syafrudin, 2011;65).

Dari uraian di atas maka peneliti tertarik untuk mencoba melakukan penelitian dengan judul "Hubungan Daya Ledak Otot Lengan dan Koordinasi Mata Tangan dengan hasil Chest Pass pada Ekstrakurikuler Bola Basket di SMP Negeri 1 Tanjung Raja”.

\section{METODOLOGI PENELITIAN}

Metode dalam penelitian ini menggunakan metode kuantitatif. Metode kuantitatif adalah data yang berbentuk angka, metode penelitian ini termasuk dalam penelitian korelasional yang bertujuan untuk mengetahui hubungan antara daya ledak otot lengan dan koordinasi mata tangan dengan hasil chest pass pada siswa ekstrakurikuler di SMP Negeri 1 Tanjung Raja.

\section{Populasi}

Tabel 1

Populasi Penelitian

\begin{tabular}{ccc}
\hline NO & Jenis Kelamin & Jumlah \\
\hline 1 & Laki-Laki & 20 \\
\hline 2 & Perempuan & - \\
\hline & Jumlah & 20 \\
\hline
\end{tabular}

Sumber : Ekstrakurikuler SMP Negeri 1 Tanjung Raja

\section{Sampel}

Seluruh populasi yang ada dijadikan sampel dalam penelitian ini. Jadi yang menjadi sampel dalam penelitian ini adalah siswa putra ekstrakurikuler SMP Negeri 1 Tanjung Raja yang berjumlah 20 Siswa.

\section{Instrumen Penelitian}

Instrumen tes dalam penelitian ini yaitu (1) duduk melempar bola two-hand medicine ball untuk mengukur daya ledak otot lengan dari Ismaryati, (2011:64), (2) lempar tangkap bola tenis untuk mengukur koordinasi mata tangan dari Ismaryati, (2011:54) dan (3) tes melempar dan menangkap bola untuk mengukur keterampilan bola basket dari Nurhasan, (2001:184).

\section{Teknik Analisis Data}

Analisis data adalah proses mencari dan menyusun secara sistematis data yang di peroleh dari hasil wawancara, catatan lapangan, dan bahan-bahan lain, sehingga dapat mudah di pahami, dan temuannya dapat di informasikan kepada orang lain. Teknik analisi data dalam penelitian ini adalah dengan menggunakan statistik assosiatif dengan product moment dengan rumus sebagai berikut :

$$
r\left(X_{1} Y\right)=\frac{N\left(\sum X_{1} Y\right)-\left(\sum X_{1}\right)\left(\sum Y\right)}{\sqrt{\left\{N \sum X_{1}^{2}-\left(\sum X_{1}\right)^{2}\right\}\left\{N \sum Y^{2}-\left(\sum Y\right)^{2}\right\}}}
$$

(Sugiyono, 2014: 233)

Keterangan :

$$
\begin{array}{ll}
\mathrm{rxy} & =\text { Korelasi antara variabel } \mathrm{x} \text { dan } \mathrm{y} \\
\mathrm{N} & =\text { Banyak sampel }
\end{array}
$$


$\sum \mathrm{X}=$ Jumlah skor dalam variabel $\mathrm{X}$

$\sum \mathrm{y} \quad=$ Jumlah skor dalam variabel $\mathrm{Y}$

$\sum X^{\wedge} 2=$ Jumlah skor yang di kuadratkan

dalam variabel $\mathrm{X}$

$\sum \mathrm{Y}^{\wedge} 2=$ Jumlah skor yang di kuadratkan dalam variable $\mathrm{Y}$

Rumus korelasi ganda :

$$
R_{y . x_{i . x_{2}}}=\sqrt{\frac{r_{y x 1} 2+2 r_{y x 1} r_{y x 2} r_{x 1 x 2}}{1-r_{x 1 x 2} 2}}
$$

(Sugiyono, 2014: 233)

Dengan Keterangan:

$$
\begin{aligned}
\mathrm{Ry} \cdot X_{I} X_{2}= & \text { Korelasi antara variabel XI } \\
& \text { dengan X2 secara bersama-sama } \\
& \text { dengan variabel y. } \\
\mathrm{ry} x_{I}= & \text { Korelasi product moment antara XI } \\
& \text { dengan y. } \\
\mathrm{ry} x_{2}= & \text { Korelasi product moment antara X2 } \\
& \text { dengan y } \\
\mathrm{r}_{I} x_{2}= & \text { Korelasi product moment antara } \\
& \text { XIdengan } X_{2}
\end{aligned}
$$

\section{HASIL DAN PEMBAHASAN}

\section{Uji Normalitas Data}

Untuk pengukuran daya ledak otot lengan (X1) skor L-hitung $=0,073$ dan L-tabel diperoleh $=0,190$,Data dikatakan berdistribusi normal apabila L-hitung < L-tabel. Sehingga disimpulkan bahwa daya ledak otot lengan berdistribusi Normal.

Untuk koordinasi mata tangan (X2) skor L-hitung $=0,101$ dan L-tabel diperoleh $=$ 0,190, L-tabel lebih besar dari L-hitung sehingga disimpukan bahwa koordinasi mata tangan berdistribusi Normal.
Untuk chest pass $(\mathrm{Y})$ skor Lhitung $=$ 0,054danLtabel diperoleh $=0,190$, Ltabellebih besar dari Lhitung sehingga disimpukan bahwa variabel Y berdistribusi Normal.

\section{Perhitungan Product Moment}

Koefisien variabel daya ledak otot lengan (X1) dengan chest pass bola basket (Y), maka mencari koefisien korelasi product moment dengan menggunakan rumus sebagai berikut:

$$
\begin{aligned}
& r\left(X_{1} Y\right)=\frac{N\left(\sum X_{1} Y\right)-\left(\sum X_{1}\right)\left(\sum Y\right)}{\sqrt{\left\{N \sum X_{1}^{2}-\left(\sum X_{1}\right)^{2}\right\}\left\{N \sum Y^{2}-\left(\sum Y\right)^{2}\right\}}} \\
& r\left(X_{1} Y\right) \\
& =\frac{20(666,7)-(46,06) \cdot(282)}{\sqrt{\left\{20.111,22-(46,06)^{2}\right\}\left\{20.4117-(282)^{2}\right\}}} \\
& r\left(X_{1} Y=\frac{13334-12988,92}{\sqrt{\{2224,4-2121,5\}\{82340-79524\}}}\right. \\
& r\left(X_{1} Y\right)=\frac{345,08}{\sqrt{\{102,9\}\{2816\}}} \\
& r\left(X_{1} Y\right)=\frac{345,08}{\sqrt{289766,4}} \\
& r\left(X_{1} Y\right)=\frac{345,08}{538,29} \\
& r\left(X_{1} Y\right)=0,641
\end{aligned}
$$

Jadi, koefisien kolerasi rx_1y adalah 0,641

Langkah selanjutnya untuk mencari variabel koordinasi mata tangan (X2) dengan hasil chest pass bola basket (Y) pada product moment sebagai berikut:

$$
r\left(X_{2} Y\right)=\frac{N\left(\sum X_{2} Y\right)-\left(\sum X_{2}\right)\left(\sum Y\right)}{\sqrt{\left\{N \sum X_{2}^{2}-\left(\sum X_{2}\right)^{2}\right\}\left\{N \sum Y^{2}-\left(\sum Y\right)^{2}\right\}}}
$$




$$
\begin{aligned}
& r\left(X_{2} Y\right) \\
& =\frac{20(3971)-(271) \cdot(282)}{\sqrt{\left\{20.3839-(271)^{2}\right\}\left\{20.4117-(282)^{2}\right\}}} \\
& r\left(X_{2} Y\right)=\frac{79420-76422}{\sqrt{\{76780-73441\}\{82340-79524\}}} \\
& r\left(X_{2} Y\right)=\frac{2998}{\sqrt{\{3339\}\{2816\}}} \\
& r\left(X_{2} Y\right)=\frac{2998}{9402624} \\
& r\left(X_{2} Y\right)=\frac{2998}{3066,36} \\
& r\left(X_{2} Y\right)=0,977
\end{aligned}
$$

Jadi, koefisien kolerasi rx_2y adalah 0,977

Selanjutnya adalah mencari r(X1X2) supaya bisa mencari data korelasi ganda, langkah selanjutnya mencari variabel daya ledak otot lengan (X1) dengan koordinasi mata tangan (X2) pada product moment sebagai berikut:

$r\left(X_{1} X_{2}\right)=\frac{N\left(\sum X_{1} X_{2}\right)-\left(\sum X_{1}\right)\left(\sum X_{2}\right)}{\sqrt{\left\{N \sum X_{1}^{2}-\left(\sum X_{1}\right)^{2}\right\}\left\{N \sum X_{2}{ }^{2}-\left(\sum X_{2}\right)^{2}\right\}}}$ $r\left(X_{1} X_{2}\right)$

$=\frac{20(643,24)-(46,06)(271)}{\sqrt{\left\{20(111,22)-(46,06\}\left\{20(3839)-(271)^{2}\right\}\right\}}}$ $r\left(X_{1} X_{2}\right)$

$=\frac{12864,8-12482,26}{\sqrt{\{2224,4-2121,52\}}\{76780-(73441)\}}$

$r\left(X_{1} X_{2}\right)=\frac{382,54}{\sqrt{\{102,87\}\{3339\}}}$

$r\left(X_{1} X_{2}\right)=\frac{382,54}{\sqrt{343504,3}}$

$r\left(X_{1} X_{2}\right)=\frac{382,54}{586,09}$

$r\left(X_{1} X_{2}\right)=0,656$

Jadi, hasil koefisien $\mathrm{r}$ x_1 x_2adalah 0,656

\section{Perhitungan Kolerasi Ganda}

Setelah menganalisis data variabel daya ledak otot lengan (X1) dengan tes chest $\operatorname{pass}(\mathrm{Y})$ dan variable koordinasi mata tangan (X2) dengan chest pass (Y), lalu menghitung antara daya ledak otot lengan (X1) dan koordinasi mata tangan (X2) dengan hasil chest pass bola basket $(\mathrm{Y})$ dengan menghitung korelasi ganda, berikut keterangannya bisa dilihat di bawah ini:

$$
\begin{aligned}
& \operatorname{Ryx}_{1} \mathrm{X}_{2}=\sqrt{\frac{r^{2} y_{x_{1}}+r^{2} y x_{2}-2 r_{y x_{1}} r_{y x_{2}} r_{x_{1 x_{2}}}}{1-\mathrm{r}^{2} x_{1 x_{2}}}} \\
& R y \cdot X_{1} \cdot X_{2}=\sqrt{\frac{0,641^{2}+0,977^{2}-2(0,641)(0,977)(0,656)}{1-(0,656)^{2}}} \\
& R y \cdot x_{1} \cdot x_{2}=\sqrt{\frac{0,410881+0,954529-(1,282)(0,640912)}{1-0,430336}} \\
& \mathrm{Ry} \cdot \mathrm{x}_{1} \cdot \mathrm{x}_{2}=\sqrt{\frac{1,3654-0,8216}{0,5696}} \\
& R y \cdot x_{1} x_{2}=\sqrt{\frac{0,5438}{0,5696}} \\
& \operatorname{Ryx}_{1} x_{2}=\sqrt{0,94} \\
& R y \cdot x_{1} \cdot x_{2}=0,969
\end{aligned}
$$

Jadi, koefesien kolerasi ganda adalah $=0,969$

Kolerasi antara daya ledak otot lengan (X1) dan koordinasi mata tangan (X2) dengan hasil chest pass (Y) dalam kolerasi ganda adalah $\mathrm{R}_{\mathrm{yx} 1 \times 2}=0,969$ dimana lebih besar dibandingkan r-tabel yang hanya 0,444 untuk jumlah sampel 20 orang.

Tarap signifikan

$$
\begin{aligned}
& F_{\text {hitung }}=\frac{\mathrm{R}^{2} / \mathrm{k}}{\left(1-\mathrm{R}^{2}\right) /(\mathrm{n}-\mathrm{k}-1)} \\
& F_{\text {hitung }}=\frac{0,969^{2} / 2}{(1-0,969) /(20-2-1)}
\end{aligned}
$$




$$
\begin{aligned}
& F_{\text {hitung }}=\frac{0,9381 / 2}{(0,062) /(17)} \\
& F_{\text {hitung }}=\frac{0,469}{0,036} \\
& F_{\text {hitung }}=13,02
\end{aligned}
$$

Kaidah pengujian sifnifikansi jika $\mathrm{f}_{\text {hitung }}$ lebih besar (>) dari $\mathrm{f}_{\text {tabel }}$ maka $\mathrm{h}_{0}$ ditolak dan ha diterima, begitupun sebaliknya jika $\mathrm{f}_{\text {hitung }}$ lebih $\operatorname{kecil}(<)$ dari $\mathrm{f}_{\text {tabel }}$ maka $\mathrm{h}_{0}$ diterima dan $\mathrm{h}_{\mathrm{a}}$ ditolak. Hasil perhitungan menghasilkan $\mathrm{f}$ hitung $=13,02$. Setelah diketahui $\mathrm{f}_{\text {hitung }}$ untuk menguji signifikasi frekuensi dicari $f_{\text {tabel. }}$ Dengan taraf signifikasi 0,05 dicari nilai $\mathrm{f}_{\text {tabel }}$.

$$
\begin{aligned}
& \mathrm{f}_{\text {tabel }}=F_{(1 .-\alpha)(d k=k)(d k=n-k-1)} \\
& \quad=F_{(1-0,05)(d k=2)(d k=20-2-1)} \\
& =F_{(0,95)(2)(17)}
\end{aligned}
$$

Dengan taraf siginifikansi 0,95 dan diketahui 2 sebagai pembilang dan 20 sebagai penyebut diketahui dari $\mathrm{f}$ tabel yaitu 2,12 Dengan demikian di dapat fhitung $=13,02>$ $\mathrm{ftabel}=2,12$ maka ho ditolak dan ha diterima artinya terdapat hubungan antara daya ledak otot lengan (X1) dan koordinasi mata tangan (X2) dengan hasil chest pass (Y)pada ekstrakurikuler bola basket di SMP Negeri 1 Tanjung Raja.

\section{Pembahasan}

Bola basket adalah olahraga bola berkelompok yang terdiri atas dua tim beranggotakan masing-masing lima orang yang saling bertanding mencetak point dengan memasukan bola dalam keranjang. olahraga basket relatif mudah di pelajari karena bolanya yang besar, sehingga tidak menyulitkan pemain ketika memantulkan atau melempar bola (Teguh Susanto, 2016:42). Dalam melakukan olahraga bola basket diperlukan kekuatan otot lengan dan koordinasi mata tangan.

Menurut Rothig at al dalam Syafrudin (2011:73), mendifinisikan bahwa Daya ledak merupakan terjemahan dari kata explosive power atau power (bahasa Inggris) dan schnelkraft $=$ power $($ bahasa Jerman). Menurut Jonath dan Krempel dalam Syafrudin (2011:74), mendifinisikan bahwa daya ledak sebagai kemampuan kombinasi kekuatan dengan kecepatan yang terealisasi dalam bentuk kemampuan otot untuk mengatasi beban dengan kecepatan kontraksi yang tinggi. Sementara menurut Harre dalam Syafrudin (2011:74), daya ledak adalah kemampuan mengatasi beban atau hambatan dengan kecepatan kontraksi otot yang tinggi.

Daya ledak merupakan kemampuan otot atau sekelompok otot untuk melakukan satu kali kontraksi secara maksimal melawan tahanan atau beban. Atau dapat didefinisikan bahwa kekuatan otot atau power adalah kemampuan otot untuk membangkitkan suatu tegangan terhadap suatu tahanan. Secara mekanis kekuatan otot didefinisikan sebagai gaya (force) yang dapat di hasilkan oleh otot atau sekelompok otot dalam suatu kontraksi maksimal. (Widiastuti, 2015:75). 
Koordinasi merupakan kemampuan untuk melakukan gerakan atau kerja dengan tepat dan efisien. Koordinasi menyatakan hubungan harmonis berbagai faktor yang terjadi pada suatu gerakan (Widiastuti, 2015:17). Dari beberapa definisi di atas dapat di definisikan bahwa koordinasi merupakan kemampuan sistem dalam persarafan pusat sebagai pengendalian suatu gerakan yang selaras dalam keharmonisan.

Berdasarkan penjelasan di atas dapat disimpulkan bahwa pada saat melakukan permainan bola basket sangat diperlukan daya ledak otot lengan dan koordinasi mata tangan pada saat melalukan passing sesama teman. Berdasarkan analisis data penelitian ini dapat disimpulkan bahwa daya ledak otot lengan (X1) memperoleh rata-rata 2,303, standar deviasi 0,52, jarak terjauh 3,20 dan jarak terdekat 1,42. Nilai koordinasi mata tangan (X2) adalah rata-rata 13,55 , standar deviasi 2,96, nilai tertinggi 18 dan nilai terendah 8 . Sedangkan nilai chest pass (Y) rata-rata adalah 14,10 , standar deviasi 2,73, nilai tertinggi 18 dan nilai terendah 8 .

Korelasi antara daya ledak otot lengan (X1) dengan chest pass(Y) adalah 0,641, korelasi antara koordinasi mata tangan (X2) dengan chest pass (Y) adalah 0,977, dan korelasi antara daya ledak otot lengan dan koordinasi mata tangan dengan chest pass adalah 0,656 dimana lebih besar dibandingkan rtabel yang hanya 0,444 yang menyatakan bahwa hubungan kedua variabel sangat kuat. Sedangkan korelasi pengujian korelasi ganda yang menunjukkan hasil yaitu $=0,969$ untuk jumlah sampel 20.

Hasil kaidah pengujian hipotesis signifikan jika fhitung lebih besar (>) dari ftabel maka ho ditolak dan ha diterima. Maka hasil perhitungan menghasilkan fhitung = 13,02> ftabel $=2,12$. Maka terdapat hubungan antara daya ledak otot lengan (X1) dan koordinasi mata tangan (X2) dengan hasil chest pass (Y) pada siswa ekstrakurikuler bola basket di SMP Negeri 1 Tanjung Raja.

\section{SIMPULAN}

Berdasarkan hasil penelitian dapat disimpulkan bahwa :

1. Ada Hubungan daya ledak otot lengan $\left(x_{1}\right)$ dengan hasil chest pass (y) bola basket adalah 0,641. Jadi, koefisien korelasi $\mathrm{r}\left(x_{1} y\right)$ adalah 0,641 .

2. Ada Hubungan koordinasi mata $\left(x_{2}\right)$ tangan dengan hasil chest pass (y) bola basket adalah 0,977. Jadi, koefisien korelasi $\mathrm{r}\left(x_{2} y\right)$ adalah 0,977 .

3. Ada Hubungan daya ledak otot lengan $\left(x_{1}\right)$ dengan koordinasi mata tangan $\left(x_{2}\right)$ adalah 0,656. Jadi, hasil koefisien $\mathrm{r}\left(x_{1} x_{2}\right)$ adalah 0,656 .

4. Dari data di atas dapat disimpulkan terdapat hubungan antara daya ledak otot lengan $\left(x_{1}\right)$ dan koordinasi mata tangan $\left(x_{2}\right)$ dengan hasil chest pass (y) pada siswa Ekstrakurikuler bola basket di SMP Negeri 1 Tanjung Raja. 


\section{DAFTAR PUSTAKA}

Alnedral. 2015. Sport Enterpreneurship. Padang: FIK UNP PRES.

Ismaryati. 2008. Tes Dan Pengukuran

Olahraga. Surakarta: (LPP) UNS Pres.

Khoeron, Nidhom. 2017. Buku Pintar Basket.

Jakarta Timur: Krati

Merio, wildan choniago.(2013). Pendidikan

olahraga dan kesehatan. (2013

Volume:1, Nomor:3, 694).

Nurhasan. 2001. Tes Dan Pengukuran Dalam Jasmani. Jakarta: Direktorat Jendral Olahraga.

Rahmani, Mikanda. 2014. Buku Super Lengkap Olahraga. Jakarta Timur: Dunia Cerdas.

Sugiyono. 2014. Metode Penelitian Kuantitatif dan R \& D. Bandung: Alfabeta.

Susanto, Teguh. 2016. Buku Pintar Olahraga. Yogyakarta: Pustaka Baru Pres.

Syafrudin. 2011. Ilmu Kepelatihan Olahraga. Padang: UNP PRES Padang.

Widiastuti. 2015. Test Dan Pengukuran.

Jakarta: Rajawali Pres. 